\title{
THE EFFECT OF GROUP TYPE COOPERATIVE LEARNING MODELS INVESTIGATION OF CONCEPTUAL KNOWLEDGE STUDENTS ON BUSINESS AND ENERGY MATERIALS
}

\author{
Lasria Lestari Situmorang $^{1 *}$, Mara Bangun Harahap ${ }^{1}$, and Indah Cahyani ${ }^{2}$ \\ ${ }^{1}$ Department of Physics Faculty of Mathematics and Natural Sciences, Medan State University \\ ${ }^{2}$ Science Department Faculty of Mathematics and Natural Sciences, Medan State University \\ * lasrialestari08@gmail.com
}

Accepted: November $11^{\text {th }}, 2019$. Published: November $26^{\text {th }}, 2019$

\begin{abstract}
This study aims to determine the effect of cooperative learning model type of group investigation on student's conceptual knowledge and activities in the subject work and energy. This research is a quasi-experiment using two-group pretest-posttest design. The study sample consisted of two classes, namely the XI MIA-1 class as the experimental class and the XI MIA-3 class as the control of which amounted to 32 students, the sampling be done with random sampling technique. The instrument used was a test of learning outcomes in the form of students conceptual knowledge in the form of 8 essay test. In the experimental class the average activity of students in the three meetings, are $60 \%, 72 \%$ and $87 \%$. From the data obtained, there is evidence of the effect of group investigation models in improving learning activity on work and energy topic in XI Senior High School 10 Medan. The hypothesis with ttest shows the result there was a significant influence of cooperative learning model type group investigation to conceptual knowledge student subject of work and energy in class XI SMA Negeri 10 Medan T.P 2018/2019.
\end{abstract}

Keywords: cooperative learning type group investigation, activities, conceptual knowledge 


\section{Introduction}

Law No. 20 of 2003 concerning the National Education System states that education is a conscious and planned effort to create an atmosphere of learning and learning process so that students actively develop their potential to have religious-spiritual power, self-control, personality, intelligence, noble character, and the necessary skills himself, society, nation and state (Sanjaya, 2006).

The main problem in learning in formal education (schools) today is the low absorption of students. This is evident from the average learning outcomes of students who are still very alarming. This achievement is certainly the result of learning conditions that are still conventional and do not touch the realm of the dimensions of the students themselves, namely how the actual learning. In a more substantial sense, that the learning process to the present still gives the dominance of the teacher and does not provide access for students to develop independence through discovery in their thought processes (Trianto, 2009).

Based on the results of an interview with one of the physics studies teachers at SMA 10 Medan, said that the average value of physics subject exams was only around 60, even though the Minimum Completion Criteria (KKM) at the school was 75. Based on a questionnaire given to 32 people students, some students show that about $66 \%$ of students rarely ask questions in front of the class while learning, $19 \%$ of students respond when teachers ask questions about the material to be studied, $15 \%$ of student teachers give examples of physics in everyday life, based on some problems that exist in the questionnaire given to students obstacles were found in the learning process.

Conceptual knowledge is the knowledge that shows the interrelationship between the basic elements in a larger structure and functions simultaneously. According to Arends (2008) there are three types of conceptual knowledge namely knowledge of clarification and categories, knowledge of principles and generalizations and knowledge of theories, models and structures.

a) Knowledge of classifications and categories Knowledge includes specific categories, classes, divisions, and arrangements in scientific disciplines. Knowledge classification and categories are the knowledge that is the basis for students in classifying information and knowledge.

b) Knowledge of principles and generalizations

Knowledge of principles and generalizations includes knowledge of certain abstractions which summarize observations of phenomena. This abstraction has the greatest benefit in describing, predicting, or determining the most appropriate and relevant action or direction to be taken. Principles and generalizations tend to be difficult for students to understand if students have not previously mastered the phenomena.

c) Knowledge of theories, models and structures Knowledge of theories, models and structures includes knowledge of principles and generalizations and the interrelations between the two that present a clear, complete and systematic view of a complex phenomenon, problem or study material. Disciplines have different paradigms and epistemologies for structuring questions, and students must know how to conceptualize the material.

In addition there are several factors that cause student grades under the KKM, one of which is the teacher's lack of applying varied learning models. The dominant teacher teaches using a direct teaching system (teacher-centred) where teachers tend to be active in the learning process and students as listeners. As a result students only memorize without understanding what is learned and its relationship in everyday life.

Efforts to overcome the above problems can be by using an effective learning model, which can increase student activity in learning activities to discover their own concepts of physics, which are student-centred according to the 2013 curriculum, and which can improve student conceptualism. The learning model which according to the author is effective is the GI learning cooperative model. The reason the authors chose the model is that this model is one of the learning models that can actively involve students since the planning of learning, both in determining the topics to be discussed and ways to overcome the problem of learning physics. The hope is that meaningful learning will occur in accordance with the constructivist paradigm. That is, in this learning active activities and knowledge are built by students and they are responsible for the learning outcomes (Arends, 2008).

The GI type cooperative model was developed based on the method developed by Sharan and Lazarowitz, which focuses on group problem-solving efforts. Learners obtain information, analyze information, provide ideas, 
and collectively solve problems or produce products. Products produced by one group may be different from other groups. Each group presents their findings in front of the class. The number of group members can consist of two to six students. The teacher evaluates the contribution of each student and assesses the group's presentation.

The GI type of cooperative learning model is a model that involves students in planning topics to be studied and how to carry out their investigations (Arends, 2008). The GI type of cooperative learning model is a model that guides students to identify topics, plan investigations in groups, carry out investigations, report, and present the results of their investigations. The GI type of cooperative learning model emphasizes collaboration between group members in finding and understanding a concept regardless of background (Simanjuntak and Siregar, 2014).

Research on the GI type cooperative model has been conducted previously by Harahap and Turnip (2014) that there is an influence of the GI type cooperative learning model on student learning outcomes on the subject matter of Newton's Law in Class X Semester I of Senior High School 14 Medan and Tumanggor and Sahyar (2015) that the learning model GI type cooperative is best applied to students who have high scientific attitude.

Based on the description above this study aims to determine the effect of the GI type of cooperative learning model on students' conceptual knowledge on business and energy material in class XI Semester I of SMA Negeri 10 Medan T.P. 2018/2019.

\section{Research Method}

This research was carried out in Medan 10 High School on Jl. Tilak No. 108, Sei Rengas I Medan Kota for class XI semester I T.P. 2018/2019. The population in this study were all grade XI students of SMA Negeri 10 Medan consisting of 4 classes. The sample in this study consisted of two classes, each of which amounted to 32 students who were chosen randomly using a cluster random sampling technique involving two classes given different treatments. Class XI MIA1 using the GI type cooperative model and class XI MIA-3 using the conventional model. The research design used was two-group pretestposttest design. The study design is shown in Table 1.
Table 1. two group pretest - posttest design

\begin{tabular}{|l|c|c|c|}
\hline \multicolumn{1}{|c|}{ Class } & Pretest & Treatment & Postest \\
\hline Experiment & $\mathrm{O}_{1}$ & $\mathrm{X}_{1}$ & $\mathrm{O}_{2}$ \\
\hline Control & $\mathrm{O}_{1}$ & $\mathrm{X}_{2}$ & $\mathrm{O}_{2}$ \\
\hline
\end{tabular}

Keterangan:

$\mathrm{O}_{1}=$ initial ability test (pretest)

$\mathrm{O}_{2}=$ last ability test (postest)

$\mathrm{X}_{1}=$ treatment in the experimental class is the application of the group investigation cooperative model

$\mathrm{X}_{2}=$ treatment in the control class is the application of conventional learning models

The data obtained were tested for normality to determine the data of the two normally distributed samples used the Liliefors test. Then the homogeneity test to find out whether the two homogeneous samples used the variance similarity test. Hypothesis testing was used the one-party ttest. If $\mathrm{F}_{\text {count }}>\mathrm{F}_{\text {table, }}$, it can be concluded that the two samples do not have a homogeneous variance with $\alpha=0.05$ ( $\alpha$ is the real level for testing).

\section{Result and Discussion}

\section{a. Result}

The results of research conducted at Medan 10 Public High School showed an average score of 42.40 for the experimental class and for the control class obtained an average value of 42.31 . In accordance with the normality test and the homogeneity test, it was found that the sample came from populations that were normally distributed and homogeneous. The data of the two samples is declared normal and homogeneous so that it is feasible to test the hypothesis and the results are shown in Table 2.

Table 2. Student's Initial Ability Test Results

\begin{tabular}{|l|l|l|l|l|}
\hline Kelas & Avg. & $\mathrm{T}_{\text {count }}$ & $\mathrm{t}_{\text {table }}$ & Conclusion \\
\hline Experiment & 42,40 & \multirow{2}{*}{0,0957} & 0,156 & $\mathrm{H}_{\mathrm{o}}$ accepted \\
\hline Control & 42,31 & & & \\
\hline
\end{tabular}

Based on Table 2 it can be concluded that $t_{\text {count }}<t_{\text {table }}$ then, $t_{\text {count }}$ falls in the area of Ho then Ho is accepted ie the initial ability of students in the experimental class is the same as the initial ability of students in the control class in business and energy.

Table 3. Research Hypothesis Test Results

\begin{tabular}{|l|l|l|l|l|}
\hline Kelas & Avg. & $\mathrm{T}_{\text {count }}$ & $\mathrm{t}_{\text {table }}$ & Conclusion \\
\hline Experiment & 78 & \multirow{2}{*}{10,83} & 1,669 & $\mathrm{H}_{\mathrm{a}}$ accepted \\
\cline { 1 - 2 } Control & 65,84 & & & \\
\hline
\end{tabular}


Based on Table 3 it can be concluded that $t_{\text {count }}$ $<\mathrm{t}_{\text {table }}$ is $10.83>1.669$ meaning Ho is rejected and $\mathrm{Ha}$ is accepted then the value of student learning outcomes in the experimental class is greater than the control class which means there is a significant effect on the GI type of cooperative learning model on students' conceptual knowledge in class XI Senior High School 10 Medan Academic Year 2018/2019.

The GI type of cooperative learning model not only influences conceptual knowledge but can also increase student learning activities.

The distribution of experimental class activity data using the GI type of cooperative learning model is shown in Table 4.

Tabel 4. Student Activity

\begin{tabular}{|l|c|l|}
\hline \multicolumn{1}{|c|}{ Pertemuan } & $\begin{array}{l}\text { Aktivitas } \\
\text { Siswa (\%) }\end{array}$ & Keterangan \\
\hline Meeting I & 60,84 & Less active \\
\hline Meeting II & 72,93 & Active Enough \\
\hline Meeting III & 87,34 & Active \\
\hline
\end{tabular}

Data on increasing student activity using the GI type cooperative learning model shows that for the experimental class from meeting I to meeting III the learning activity using the GI type cooperative learning model has increased. This student activity has a positive influence on conceptual knowledge.

\section{b. Discussion}

The GI type of learning model can increase students' conceptual knowledge and student activities that are more active in the learning process. The superiority of GI students is observing, reasoning, asking questions and communicating with group members in ongoing learning activities. Through the application of the GI type cooperative learning model students are active in the initial steps of group formation and topic selection students are directly involved in discovering physics concepts through group experiments, according to Putri's (2014) opinion in the GI type cooperative learning model students are given control in selecting topics for plan what you want to learn and investigate.

The second step students identify learning topics that have been determined by the teacher and students plan the goals and steps of learning based on sub-topics and selected material. In line with Kusmayadi and Retno (2014) on the GI type of cooperative learning model students choose the sub-topics they will study and topics that have usually been determined by the teacher.
The third step, the implementation of research or implementation, will be conducted experiments where each group receives tools and materials, as well as student worksheets (LKPD) at the implementation stage students, collect facts from various sources to analyze the problem topics they discuss from relevant sources. In accordance with the opinion of Siregar and Harahap (2016) after each member worked in accordance with their duties, then a group discussion was held for this research or investigation process, they would be involved in higher-level thinking activities, such as making synthesis, summaries and hypotheses.

The fourth step Analysis and Synthesis, each group member completes a report of the research results or prepares a final group report from each group member. In line with the opinion of Siregar and Harahap (2016) that after each member worked in accordance with their duties, a group discussion was then held to conclude the results of the study and Irwan and Sani (2015), namely the preparation of the final report after the research was made, then the final research report was written.

The fifth step, the presentation of the final report and drawing conclusions, students present research results in front of the class obtained at the time of implementation, in line with the opinions of Limbong and Rahmatsyah (2017) present the final report.

The sixth step, evaluation. At the evaluation stage students provide suggestions and criticisms obtained in the class discussion forum in accordance with the opinions of Elinda and Bukit (2015), ie each group evaluates the results of their research and Yusniati and Yusuf (2016) that at the evaluation stage an increase in the investigation.

Conceptual Knowledge Students in the experimental class showed an increase. This can be seen from the acquisition of the average value of conceptual knowledge at the time of the initial ability test (pre-test) and the final ability test (post-test), namely at the time of the pre-test obtained an average value of 42.40 and at the post-test of 78 . The difference in the average value in the pre-test and post-test indicates the difference in students 'conceptual knowledge before and after being given treatment, where students' conceptual knowledge after being treated is better than before being treated, this is because when students treated by using the GI Type Cooperative learning model students will be actively involved since the planning of learning, both in determining the topics to be discussed as well as ways to overcome the problems of learning physics. 
The control class of students is taught by using conventional learning and the result is an increase in students' conceptual knowledge but the results are not significant, where the average pre-test score is 42.31 while the average post-test score is 65.84 . The magnitude of the increase in students' conceptual knowledge in the control class is still lower when compared to the experimental class using the GI Type Cooperative learning model. This is due to conventional learning which is only conveying information verbally to a number of students. Learning activities in the control class are centred on lecturer and unidirectional communication. In conventional learning in this control class, students learn by listening more to the teacher's explanation in front of the class and carrying out assignments if given a question exercise by the teacher to students. The conventional learning system that is carried out in the learning process in the control class is by using lecture, question and answer and demonstration methods, so students feel bored, passive and forgetful. This is what causes learning outcomes in the control class to be lower than learning outcomes in the experimental class.

During the learning process, the researcher observed the activities of students who were assisted by three observers, of which the three observers were fellow researchers. Observation of student activities consists of three meetings. The activities observed in students are the phases in the GI Type Cooperative learning model, namely: 1) Selecting a topic that is suitable for the subject matter; 2) Knowing the learning tasks to be performed; 3) Conducting Experiments; 4) Prepare the final report; 5) Present the final report; 6) Formulating conclusions.

Based on observations and assessments made by observers when carrying out the phases of the GI type cooperative learning model at each meeting, the average value of activity at meeting I was $60.84 \%$ which was classified as quite an active category, meeting II with an average value of $72,93 \%$ were helpful in the active category, and in meeting III with an average value of $87.34 \%$ were in the active category.

\section{Conclusion}

Based on the research results obtained it can be concluded that there is an influence of the GI type of cooperative learning model on students' conceptual knowledge on business material and energy in class XI Semester I of Senior High School 10 Medan Academic Year 2018/2019 and increasing student learning activities.

\section{Reference}

Arends, R. I., (2008), Laerning To Teach, Yogykarta: Pustaka Belajar.

Elida, T., dan Bukit, N., (2015), Analisis Pengaruh Model Pembelajaran Kooperatif Tipe Group Investigation dan Pemahaman Konsep Awal terhadap Hasil Belajar Siswa di SMAN 1 Teluk Mengkudu, Jurnal Pendidikan Fisika, 4(1), 49-56.

Harahap, R., dan Turnip, B.M., (2014), Pengaruh Model Pembelajaran Kooperatif Tipe Group Investigation (GI) Berbantu Media Flash terhadap Hasil Belajar Fisika Siswa SMA, Jurnal Inpafi, 2(3), 156163.

Irwan, N., dan Sani, R.A., (2015), Efek Model Pembelajaran Kooperatif Tipe Group Investigation dan Teamwork Skills Terhadap Hasil Belajar Fisika, Jurnal Pendidikan Fisika, 4(1), 41-48.

Kusmayadi, T. dan A., Retno, E. W., (2014), Pengembangan Model Pembelajaran Group Investigation (GI) Berbantu Video Camtasia Pada Materi Peluang Untuk Siswa SMAN Kabupaten Cilacap, Jurnal Elektronik Pembelajaran Matematika, 2(5), 478-490.

Limbong, D., dan Rahmatsyah, (2017), Pengaruh Model Pembelajaran Kooperatif Group Investigation Terhadap Hasil Belajar Siswa Pada Materi Usaha dan Energi di Kelas X, Jurnal Geliga Sains 5 (2), 119124.

Putri, R., (2014), Penerapan Model Pembelajaran GI (Group Investigation) Untuk Meningkatkan Aktivitas Dan Prestasi Belajar Fisika Siswa Kelas X Multimedia 2 SMA Nasional Malang, Jurnal Pembelajaran Fisika, 2(3).

Sanjaya, w., (2010), Strategi Pembelajaran Berorientasi Standar Proses Pendidikan, Kencana, Jakarta.

Simanjuntak, S. L., dan Siregar, N., (2014), Pengetahuan Model Pembelajaran Kooperatif Tipe Group Investigation terhadap Hasil Belajar pada Materi 
Listrik Dinamis, Jurnal Inpafi, 2(2), 171179.

Siregar, E., dan Harahap, M,B., (2016), Pengaruh Model Pembelajaran Kooperatif Tipe Group Investigation (GI) Terhadap Pengetahuan Konseptual Siswa SMA Muhammadiyah 2 Medan T.P. 2015/2016, Jurnal Inpafi, 4(4).

Tumanggor, A., dan Sahyar, (2015), Analisis Model Pembelajaran Kooperatif Tipe Group Investigation Berbasis Kolaboratif Dan Sikap Ilmiah Terhadap Hasil Belajar Fisika Siswa SMAN 1 Secanggang, Jurnal Pendidikan Fisika, 4(2), 21-28.

Trianto, (2010), Model-Model Pembelajaran Inofatif - Progresif, Kencana Prenada Media Group, Jakarta.

Yusniati, H., dan Yusuf. M., (2016), Penerapan Model Pembelajaran Kooperatif Tipe Group Investigation Untuk Meningkatkan Hasil Belajar Fisika Hukum Newton Tentang Gravitasi Pada Siswa Kelas X1 IPA ${ }^{1}$ SMA Negeri 7 Kupang, Jurnal Sains Pendidikan Fisika, Jilid 12(1), 1-13. 